\title{
PEMBERDAYAAN MASYARAKAT HOME INDUSTRI DALAM RANGKA MENDORONG KEMANDIRIAN EKONOMI
}

\author{
Warter Agustim \\ Program Studi Manajemen \\ Fakultas Ekonomi Universitas Tribhuwana Tunggadewi Malang \\ Jalan Telaga Warna, Telogomas-Lowokwaru Malang
}

\begin{abstract}
Development in harmony is needed, between the buffer zones and urban areas. Development in harmony must demonstrate the important role of buffer zones to urban areas because of the synergy potential of different regions and need each other. So by knowing the potential of each area required mapping potential areas can provide a buffer for future development plans. This study has the objective to provide information to SMEs located in the Donowarih Village, Karangploso District., Malang Regency, which has good characteristics as a buffer zone for the surrounding urban environment. This study used a qualitative descriptive method. The study states that the majority of SMEs in the village Donowarih still using simple management in the management of its business. Many factors are influential in this regard, education, mental, environmental and other factors. Based on the need for repair and improvement programs that can improve the ability of SMEs and the other is the most important thing the government can directly determine program development program that is in harmony with the state of local characteristics.
\end{abstract}

\begin{abstract}
ABSTRAK
Pembangunan secara selaras sangat dibutuhkan, antara daerah penyangga dan daerah perkotaan. Pembangunan yang selaras harus menunjukkan peran penting dari daerah penyangga yang sinergi terhadap daerah perkotaan karena potensi daerah yang berbeda dan saling membutuhkan. Maka dengan mengetahui potensi daerah masing-masing diperlukan pemetaan potensi daerah penyangga untuk dapat memberikan rencana pembangunan ke depannya. Penelitian ini mempunyai tujuan untuk memberikan informasi mengenai UMKM yang terdapat di Desa Donowarih, Kecamatan Karangploso, Kabupaten Malang, yang mempunyai karakteristik yang baik sebagai daerah penyangga bagi lingkungan perkotaan di sekelilingnya. Penelitian ini menggunakan metode deskriptif kualitatif. Hasil penelitian menyatakan bahwa mayoritas dari pelaku UMKM di Desa Donowarih masih menggunakan manajemen sederhana dalam pengelolaan usahanya. Banyak faktor yang berpengaruh dalam hal ini: pendidikan, mental, lingkungan dan faktor yang lain. Berdasarkan hal tersebut perlu adanya perbaikan dan peningkatan program-program yang dapat meningkatkan kemampuan pelaku UMKM dan hal terpenting yang lain adalah pemerintah secara langsung dapat menentukan
\end{abstract}


program-program pembangunan yang selaras dengan keadaan karakteristik suatu daerah.

Keywords: buffer zone, UMKM, characteristic.

\section{PENDAHULUAN}

Pembangunan dari suatu wilayah memerlukan adanya kerjasama yang baik antara daerah pedesaan ataupun daerah pinggiran. Hal ini dibutuhkan agar efek dari pembangunan dapat dirasakan lebih merata berdasarkan potensi dari masing-masing daerah pinggiran. Wilayah yang tidak merupakan daerah pusat dari perekonomian cenderung mempunyai perbedaan ataupun kesenjangan, yang bisa mengakibatkan ketimpangan partisipatif dalam pembangunan dan membuat masyarakat yang tinggal di daerah pinggiran tidak merasakan pembangunan ini.

Pemberdayaan masyarakat pada dasarnya pokok pikiran dari teori pembangunan yang berpusat pada rakyat (people centered development) yang dalam implementasinya dijabarkan ke dalam pendekatan pemberdayaan masyarakat, yaitu adanya pendekatan yang memberikan kesempatan yang lebih luas bagi masyarkat lokal untuk lebih berpartisipasi dalam pembangunan sesuai dengan potensi yang dimiliki (Soetomo, 2011).

Usaha Mikro, Kecil dan Menengah (UMKM) di tiap daerah di Indonesia terutama di Kabupaten Malang memang tergolong besar. Beberapa kecamatan dan desa seputaran Kabupaten Malang mempunyai variasi potensi yang menjanjikan berdasarkan atas karakteristik dalam daerah masing-masing, dari pertambangan, pertanian, perkebunan ataupun bidang-bi- dang yang lain. Tapi di sisi yang lain informasi terhadap keberadaan dan fungsi bagaimana UMKM ini dapat memberikan kontribusi terhadap pertumbuhan ekonomi untuk daerahnya sendiri ataupun daerah perkotaan sangatlah minim. Karenanya inventarisasi dan pemetaan UMKM daerah penyangga dianggap perlu.

Pada penelitian ini akan dilihat pemetaan potensi UMKM di Desa Donowarih dan fungsinya sebagai Daerah Penyangga (Buffer Zone). Di samping itu juga akan dilihat bagaimana pengaruh UMKM di Daerah Donowarih dalam meningkatkan kesejahteraan masyarakat Desa Donowarih.

Desa Donowarih merupakan salah satu desa di Kecamatan Karangploso Kabupaten Malang Provinsi Jawa Timur yang berlokasi di seputaran lereng Gunung Arjuna dengan Topografi berupa dataran dan perbukitan serta berada pada ketinggian 600 sampai dengan $850 \mathrm{~m}$ dari permukaan air laut, sehingga mengakibatkan desa ini berhawa sejuk dan dingin. Luas wilayah 1.298,018 ha, pemanfaatan lahan untuk pemukiman, lahan persawahan, ladang, perkebunan, hutan dan lain-lain. Desa Donowarih termasuk mempunyai tanah yang subur untuk usaha pertanian, sehingga masyarakat sebagian besar mempunyai usaha pertanian sayur-mayur, padi, jagung, tanaman buah-buahan (apel, jeruk), kopi, tebu pada lahan basah dan kering. Selain itu banyak sektor usaha non 
pertanian yang berkembang di Desa Donowarih.

Penelitian ini bertujuan untuk mengetahui peta potensi UMKM di Desa Donowarih dalam fungsinya sebagai Daerah Penyangga (Buffer Zone). Di samping itu penelitian ini juga bertujuan untuk mengetahui bagaimana kontribusi UMKM di Desa Donowarih dalam peningkatan kesejahteraan masyarakat di Desa Donowarih. Penelitian ini dibatasi hanya meneliti pada UMKM di Desa Donowarih, Kecamatan Karangploso, Kabupaten Malang dan hanya meneliti dari aspek pemasaran, serapan sumber daya manusia, operasional, dan keuangan.

\section{TINJAUAN PUSTAKA}

\section{Pemberdayaan Masyarakat}

Memberdayakan masyarakat adalah sebuah pendekatan yang memberikan kesempatan, wewenang yang lebih besar kepada masyarakat terutama masyarakat lokal untuk mengelola proses pembangunannya. Kewenangan tersebut meliputi keseluruhan proses pembangunan sejak identifikasi masalah dan kebutuhan, perencanaan, pelaksanaan, evaluasi dan menarik manfaat hasil pembangunan (Soetomo, 2011).

Pemberdayaan masyarakat berarti meningkatkan kemampuan atau meningkatkan kemandirian masyarakat. Menurut Sumodiningrat (2002) dalam kerangka pembangunan nasional, upaya pemberdayaan masyarakat dapat di lihat dari sisi:

1. Menciptakan suasana atau iklim yang memungkinkan masyarakat berkembang.

2. Meningkatkan kemampuan masyarakat dalam membangun prasarana dan sarana fisik maupun sosial, serta pengembangan lembaga di daerah.

3. Melindungi/memihak yang lemah untuk mencegah persaingan yang tidak seimbang dan menciptakan kemitraan saling menguntungkan.

Peraturan Menteri Dalam Negeri Republik Indonesia Nomor 7 Tahun 2007 pasal 1 ayat (8) menyatakan bahwa pemberdayaan masyarakat adalah suatu strategi yang digunakan dalam pembangunan masyarakat sebagai upaya untuk mewujudkan kemampuan dan kemandirian dalam kehidupan bermasyarakat, berbangsa dan bernegara. Inti pengertian pemberdayaan masyarakat merupakan strategi untuk mewujudkan kemampuan dan kemandirian masyarakat (Cholisin, 2011)

Konsep pemberdayaan (masyarakat desa) dapat pula dipahami dalam konteks menempatkan posisi berdiri masyarakat. Posisi masyarakat bukanlah obyek penerima manfaat (beneficiaries) yang tergantung pada pemberian dari pihak luar seperti pemerintah, melainkan dalam posisi sebagai subjek (agen atau partisipan yang bertindak) yang berbuat secara mandiri.

\section{Pengertian Usaha Mikro, Kecil dan Menegah Usaha Mikro}

Undang-Undang Republik Indonesia Nomor 20 Tahun 2008 tentang Usaha Mikro, Kecil dan Menengah merumuskan bahwa usaha mikro adalah usaha produktif milik orangperorangan dan atau badan usaha milik perorangan dengan kriteria memiliki kekayaan bersih paling banyak Rp. 50.000.000,- tidak termasuk tanah dan bangunan tempat usaha atau memiliki hasil penjualan tahunan paling banyak Rp. 300.000.000,-. 
Usaha mikro tergolong jenis usaha marginal, ditandai dengan penggunaan teknologi yang relatif sederhana, tingkat modal dan akses terhadap kredit yang rendah, serta cenderung berorientasi pada pasar lokal. Namun demikian sejumlah kajian di beberapa negara menunjukkan bahwa usaha mikro berperanan cukup besar bagi pertumbuhan ekonomi, menyerap tenaga kerja melalui penciptaan lapangan pekerjaan, menyediakan barang dan jasa dengan harga murah, serta mengatasi masalah kemiskinan.

\section{Usaha Kecil}

Definisi usaha kecil menurut Undang-Undang Republik Indonesia Nomor 20 Tahun 2008 tentang Usaha Mikro, Kecil dan Menengah adalah usaha ekonomi produktif yang berdiri sendiri yang dilakukan oleh orangperorangan atau yang dilakukan badan usaha yang bukan merupakan anak perusahaan atau bukan cabang perusahaan yang dimiliki, dikuasai, atau menjadi bagian baik langsung maupun tidak langsung dari usaha menengah atau usaha besar yang memenuhi kriteria usaha kecil sebagaimana dimaksud dalam Undang-Undang.

Kriteria usaha kecil menurut Undang-Undang Republik Indonesia Nomor 20 Tahun 2008 tentang Usaha Mikro, Kecil dan Menengah, antara lain:

1. Memiliki kekayaan bersih lebih dari Rp. 50.000.000,- sampai dengan paling banyak Rp. 500.000.000,tidak termasuk tanah dan bangunan tempat usaha; atau

2. Memiliki hasil penjualan tahunan lebih dari Rp. 300.000.000,- sampai dengan paling banyak Rp. 2.500.000.000,-.
Usaha kecil merupakan usaha yang integral dalam dunia usaha nasional yang memiliki kedudukan, potensi, dan peranan yang signifikan dalam mewujudkan tujuan pembangunan nasional pada umumnya dan pembangunan ekonomi pada khususnya. Selain itu, usaha kecil juga merupakan kegiatan usaha dalam memperluas lapangan pekerjaan dan memberikan pelayanan ekonomi yang luas, agar dapat mempercepat proses pemerataan pendapatan ekonomi masyarakat.

\section{Usaha Menengah}

Usaha menengah sebagaimana dimaksud dalam Undang-Undang Republik Indonesia Nomor 20 Tahun 2008 tentang Usaha Mikro, Kecil dan Menengah adalah usaha ekonomi produktif yang berdiri sendiri, yang dilakukan oleh orang-perseorangan atau badan usaha yang bukan merupakan anak perusahaan atau cabang perusahaan yang dimiliki, dikuasai, atau menjadi bagian baik langsung maupun tidak langsung dengan usaha kecil atau usaha besar dengan jumlah kekayaan bersih atau hasil penjualan tahunan sebagaimana diatur dalam Undang-Undang.

Kriteria usaha menengah menurut Undang-Undang Republik Indonesia Nomor 20 Tahun 2008 tentang Usaha Mikro, Kecil dan Menengah, antara lain:

1. Memiliki kekayaan bersih lebih dari Rp. 500.000.000,- sampai dengan paling banyak Rp. 10.000.000.000,- tidak termasuk tanah dan bangunan tempat usaha; atau

2. Memiliki hasil penjualan tahunan lebih dari Rp. 2.500.000.000,- 
sampai dengan paling banyak Rp. 50.000.000.000,--

Ciri-ciri usaha menengah, antara lain:

1. Pada umumnya telah memiliki manajemen dan organisasi yang lebih baik, lebih teratur bahkan lebih modern, dengan pembagian tugas yang jelas antara lain: bagian keuangan, bagian pemasaran dan bagian produksi.

2. Telah melakukan manajemen keuangan dengan menerapkan sistem akuntansi yang teratur, sehingga memudahkan untuk auditing dan penilaian atau pemeriksaan termasuk oleh perbankan.

3. Telah melakukan aturan atau pengelolaan organisasi perburuhan, telah ada jamsostek, pemeliharaan kesehatan dan lain-lain.

4. Sudah memiliki segala persyaratan legalitas antara lain: izin tetangga, izin usaha, izin tempat, NPWP, upaya pengelolaan lingkungan dan lain-lain.

5. Sudah mempunyai akses kepada sumber-sumber pendanaan perbankan.

6. Pada umumnya telah memiliki sumber daya manusia yang terlatih dan terdidik.

\section{Pemberdayaan UMKM}

Dalam Undang-Undang Republik Indonesia Nomor 20 Tahun 2008 tentang Usaha Mikro, Kecil dan Menengah telah didefinisikan bahwa pemberdayaan adalah upaya yang dilakukan Pemerintah, Pemerintah Daerah, Dunia Usaha, dan Masyarakat secara sinergis dalam bentuk penumbuhan iklim dan pengembangan usaha terhadap UMKM, sehingga mampu tumbuh dan berkembang menjadi usaha yang tangguh dan mandiri.
Dalam rangka pemberdayaan UMKM, keterlibatan stakeholder sangat menentukan keberhasilannya. Sejauh ini keterlibatan stakeholder UMKM antara lain terdiri dari: instansi pemerintah, lembaga pendidikan, LSM, koperasi, perbankan dan asosiasi usaha (Sudrajat. 2012).

Menurut Karsidi dan Irianto (2005) dalam Sudrajat (2012) keterlibatan yang ada masih bersikap sendirisendiri dan kurang intergratif antara stakeholder satu dengan yang lain. Berikut diberikan pola alternatif hubungan antar peran masing-masing stakeholder UMKM yang diharapkan mampu memberikan sumbangan yang signifikan bagi kemajuan UMKM:

1. UMKM sebagai pelaku memegang peran yang sangat kunci dalam rangka pemberdayaan mereka sendiri.

2. Kelompok/Koperasi. Beragamnya jenis usaha dan skala usaha memang memerlukan beragam perlakuan yang berbeda.

3. BDS (Bussines Development Services) ini berperan sebagai konsultan pengembang usaha dalam berbagai aspek, seperti aspek manajemen, produksi, pasar dan pemasaran bahkan sampai fasilitasi dalam menghubungkan UMKM ke lembaga keuangan baik bank maupun non bank.

4. Asosiasi Usaha dapat membantu UMKM dalam berbagai aspek melalui anggotanya terutama dalam hal ini kaitannya dengan pasar akan memperkuat posisi tawar dalam perdagangan, baik dalam harga maupun sistem pembayaran dan meciptakan persaingan usaha yang sehat.

5. Lembaga Keuangan (Bank dan Non Bank) salah satu masalah klasik 
pemberdayaan UMKM adalah masalah kekurangan modal, namun UMKM enggan untuk datang ke bank khususnya karena terkait oleh banyaknya persyaratan yang diperlukan untuk memperoleh fasilitasi kredit dari perbankan.

6. Pasar perdagangan hasil produksi UMKM dapat berupa pasar dalam negeri (domestik) maupun pasar ekspor.

7. Pemerintah mempunyai peran dalam memfasilitasi UMKM Lembaga lain yang terkait dengan pemberdayaan UMKM seperti koperasi, Asosiasi, BDS, dan lembaga keuangan dapat digerakkan oleh pemerintah dengan kebijakan tertentu.

Langkah-langkah yang harus ditempuh untuk mempercepat pemberdayaan UMKM antara lain: (1) tersedianya SDM yang berkualitas dan profesional, (2) tersedianya dukungan regulasi yang kondusif, (3) tersedianya pengawasan yang efektif, (4) tersedianya teknologi informasi yang murah, dan (5) tersedianya pembiayaan modal yang mudah diakses (Baseline Report, 2000 dalam Assery, 2009).

\section{Pendapatan Masyarakat Desa}

Pendapatan masyarakat yang merata sebagai suatu sasaran merupakan masalah yang sulit dicapai, namun berkurangnya kesenjangan adalah salah satu tolok ukur keberhasilan pembangunan.

\section{METODE PENELITIAN Lokasi Penelitian}

Penelitian ini dilaksanakan di Desa Donowarih yang berada di salah satu desa di wilayah Kecamatan Ka- rangploso, Kabupaten Malang. Desa Donowarih mempunyai banyak potensi baik dari alam dan lokasi. Satu hal potensi yang dimiliki adalah lokasi yang berbatasan dengan Kota Wisata Batu, Kabupaten Malang Utara dan Kota Malang. Keunggulan ini diikuti dengan keunggulan lain, misalnya Pertanian, Perkebunan, Kehutanan, dan Wisata.

Desa Donowarih merupakan desa yang memiliki 4 (empat) dukuh yaitu: Dukuh Karangan, Dukuh Borogragal, Dukuh Jaraan, dan Dukuh Karangjuwet. Setiap dukuh mempunyai potensi tersendiri. Dalam penelitian ini akan dilakukan pemetaan (mapping) UMKM yang berkembang di desa tersebut.

Penelitian lapangan dilakukan di 4 (empat) dukuh yang terdapat di Desa Donowarih. Hal ini dilakukan karena setiap dukuh mempunyai potensi yang berbeda-beda berdasarkan sumber daya manusia dan alam. Selain ini pemilihan wilayah penelitian juga mempertimbangkan keterwakilan dengan harapan diperoleh variasi. Pemilihan UMKM di Desa Donowarih didasarkan berbagai komponen ciriciri dari usaha mikro, kecil dan menengah berdasarkan jenis usaha, pemasaran, sumber daya manusia, operasional dan keuangan.

Selain data primer yang didapat dan data lainnya, juga dikumpulkan data dan infomasi sekunder tentang masing-masing upaya dan keberadaan UMKM termasuk jumlah usaha mikro dan data lain yang berkatian dengan usaha mikro. Letak geografis dan topografi dari Desa Donowarih dapat dilihat pada Tabel 1. 
Tabel 1

Letak Geografis dan Topografi Desa Donowarih

\begin{tabular}{|c|c|c|c|c|}
\hline Batas Wilayah & Orbitasi Desa & $\begin{array}{c}\text { Kondisi } \\
\text { Geografis Desa }\end{array}$ & Topografi & $\begin{array}{c}\text { Wilayah } \\
\text { Administrasi }\end{array}$ \\
\hline $\begin{array}{l}\text { Sebelah Utara: } \\
\text { Desa Bocek dan } \\
\text { hutan lindung }\end{array}$ & $\begin{array}{l}\text { Jarak tempuh ke Ibukota } \\
\text { Kecamatan: } 0,9 \mathrm{Km} \\
\text { Waktu tempuh ke Ibukota } \\
\text { Kabupaten: } 1 \text { jam }\end{array}$ & $\begin{array}{l}\text { Ketinggian tempat } \\
\text { dari permukaan air } \\
\text { laut: } 720 \mathrm{~m}\end{array}$ & $\begin{array}{l}\text { Dataran: } \\
239.814\end{array}$ & $\begin{array}{l}\text { Jumlah } \\
\text { Pedukuhan: } 4 \\
\text { dukuh } \\
\text { Jumlah RW: } 12 \\
\text { RW } \\
\text { Jumlah RT: } 52 \text { RT }\end{array}$ \\
\hline $\begin{array}{l}\text { Sebelah Timur: } \\
\text { Desa Girimoyo dan } \\
\text { Bocek }\end{array}$ & $\begin{array}{l}\text { Jarak tempuh ke Ibukota } \\
\text { Kabupaten: } 18 \mathrm{Km}\end{array}$ & $\begin{array}{l}\text { Curah hujan } \\
\text { rata-rata pertahun: } \\
250 \mathrm{~mm}\end{array}$ & $\begin{array}{l}\text { Perbukitan: } \\
1.058 .204\end{array}$ & \\
\hline $\begin{array}{l}\text { Sebelah Selatan: } \\
\text { Desa Pendem, } \\
\text { Kecamatan Junrejo Kota } \\
\text { Batu }\end{array}$ & $\begin{array}{l}\text { Jarak tempuh ke Ibukota } \\
\text { Provinsi: } 81 \mathrm{Km}\end{array}$ & $\begin{array}{l}\text { Keadaan suhu rata- } \\
\text { rata: } 27^{\circ} \mathrm{C}\end{array}$ & & \\
\hline $\begin{array}{l}\text { Sebelah Barat: } \\
\text { Desa Tawangargo }\end{array}$ & $\begin{array}{l}\text { Waktu tempuh ke Ibukota } \\
\text { Kecamatan: } 15 \text { menit }\end{array}$ & & & \\
\hline
\end{tabular}

Penentuan sampel UMKM yang terlibat dalam penelitian ini menggunakan metode Snow Ball Sampling, yaitu penentuan sampel lembaga pemasaran yang mula-mula berdasarkan informasi dari sumbersumber yang terpercaya, misal Pemerintah desa dan Lingkungan Peme- rintah Dukuh. Model ini digunakan karena target populasi lembaga pemasaran tidak diketahui dengan jelas dan sulit didekati dengan cara lainnya. Metode Penetapan Sampel di atas secara skematis dapat dilihat seperti pada Gambar 1.

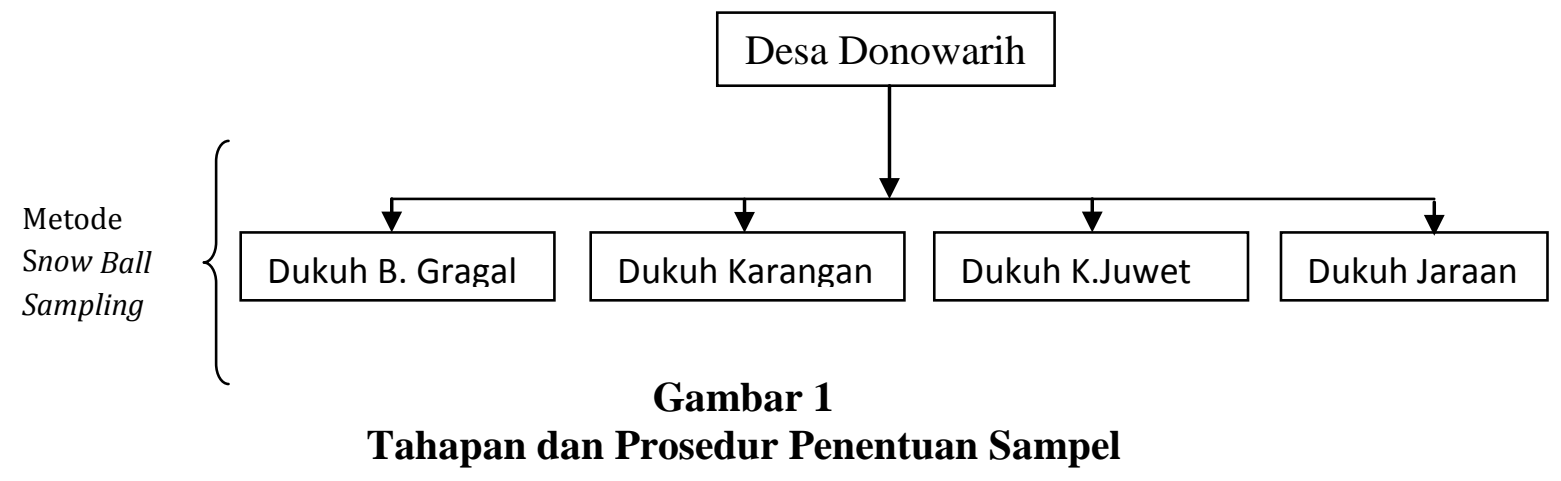

\section{Teknik Pengumpulan Data}

Data yang diperlukan dalam penelitian dapat dikelompokkan atas data primer dan data sekunder. Data sekunder dikumpulkan dari dokumentasi pada berbagai instansi terkait dan berbagai sumber resmi lainnya.
Pengambilan data primer dilakukan melalui wawancara dengan pemilik usaha UMKM. Wawancara dilakukan dengan berpedoman pada kuesioner yang telah dibuat, observasi langsung dan mengumpulkan catatan yang dibuat. 


\section{Analisis Data}

Data yang diperoleh ditabulasi kemudian dianalisis menggunakan metode fish bone yang mana merupakan alat yang efektif dan mengenali situasi yang sebenarnya. Adapun langkah-langkahnya adalah sebagai berikut:

1. Tentukan masalah-masalah spesifik.

2. Tentukan karakteristik dari masalah tersebut.

3. Tentukan penyebab utama dari permasalahan tersebut.

4. Analisis kembali dan definisikan penyebab yang ada.

5. Buatlah brainstorming dengan berbagai pihak.

\section{HASIL PENELITIAN}

Secara umum peran UMKM bagi perkembangan ekonomi di Indonesia sangat penting terutama dalam penyerapan tenaga kerja. Misal pada masa krisis ekonomi tahun 1998, UMKM memiliki ketahanan yang lebih baik. Berdasarkan data BPS, pada tahun 2009 ada 51.127.537 unit atau sekitar 99.99\% usaha yang terdapat di Indonesia adalah UMKM. Karena besarnya kuantitas jumlah UMKM, maka penyerapan tenaga kerja pada sektor ini sangatlah besar yaitu 97,04 \%. Tabel 2 menunjukkan gambaran skala usaha di Indonesia dan kontribusinya terhadap perekonomian nasional.

Tabel 2

Gambaran Skala Usaha

\begin{tabular}{|c|c|c|c|}
\hline No & Jenis Usaha & Definisi & Peran dalam Perekonomian \\
\hline 1. & Usaha Besar & $\begin{array}{l}\text { - Kekayaan bersih } \\
\text { di atas Rp. } 10 \mathrm{M} \text { atau } \\
\text { - Hasil Penjualan } \\
\text { di atas Rp. } 50 \mathrm{M} / \\
\text { tahun }\end{array}$ & $\begin{array}{l}\text { - Jumlah unit usaha } \pm 4.372 \text { unit }(0,01 \%) \\
\text { - Sumbangan terhadap: } \\
\text { > Tenaga kerja: } 2,96 \% \\
>\text { PDB: } 44,44 \% \\
>\text { Ekspor Non Migas: } 70,83 \% \\
>\text { Investasi: } 47,11 \% \\
\end{array}$ \\
\hline 2. & $\begin{array}{l}\text { Usaha } \\
\text { Menengah }\end{array}$ & $\begin{array}{l}\text { - Kekayaan bersih } \\
\text { di atas Rp. } 500 \text { juta - } \\
\text { Rp. } 10 \text { milyar atau } \\
\text { - Hasil Penjualan } \\
\text { di atas Rp. 2,5 milyar - } \\
\text { Rp. } 50 \text { milyar/tahun } \\
\end{array}$ & $\begin{array}{l}\text { - Jumlah unit usaha } \pm 39.657 \text { unit }(0,08 \%) \\
\text { - Sumbangan terhadap: } \\
\text { > Tenaga kerja: } 3,48 \% \\
>\text { PDB: } 3,43 \% \\
>\text { Ekspor Non Migas: } 13,10 \% \\
>\text { Investasi: } 23,81 \% \\
\end{array}$ \\
\hline 3. & Usaha Kecil & $\begin{array}{l}\text { - Kekayaan bersih } \\
\text { di atas Rp. } 50 \text { juta - } \\
\text { Rp. } 500 \text { juta atau } \\
\text { - Hasil Penjualan } \\
\text { di atas Rp. } 300 \text { juta - } \\
\text { Rp. 2,5 milyar/tahun }\end{array}$ & $\begin{array}{l}\text { - Jumlah unit usaha } \pm 520.221 \text { unit }(1,01 \%) \\
\text { - Sumbangan terhadap: } \\
\text { > Tenaga kerja: } 4,26 \% \\
\text { > PDB: } 10,08 \% \\
>\text { Ekspor Non Migas: } 4,85 \% \\
>\text { Investasi: } 20,69 \%\end{array}$ \\
\hline 4. & Usaha Mikro & $\begin{array}{l}\text { - Kekayaan bersih } \\
\text { di atas Rp. } 50 \text { juta atau } \\
\text { - Hasil Penjualan } \\
\text { kurang dari Rp. } 300 \\
\text { juta/tahun }\end{array}$ & $\begin{array}{l}\text { - Jumlah unit usaha } \pm 50.567 .659 \text { unit (98,90\%) } \\
\text { - Sumbangan terhadap: } \\
\text { > Tenaga kerja: 89,30\% } \\
>\text { PDB: 32,05\% } \\
\text { > Ekspor Non Migas: } 2,22 \% \\
>\text { Investasi: } 8,39 \% \\
\end{array}$ \\
\hline
\end{tabular}

Sumber: Publikasi BI, BPS, dan Kemenkop dalam Payu dan Dai (2014) 
Dari hasil penelitian diketahui jumlah unit usaha UMKM di Desa Donowarih lebih dari 555 unit usaha. Dari jumlah unit usaha tersebut diambil sebanyak 248 unit usaha sebagai sampel dalam penelitian ini yang tersebar pada 4 dusun/dukuh yaitu Dusun Karangjuwet, Dusun Jaraan, Dusun Karangan dan Dusun Borogragal. Sebaran jumlah UMKM yang menjadi sampel pada masingmasing dukuh/dusun terlihat pada Tabel 3 di bawah ini.

Tabel 3

Sebaran UMKM di Desa Donowarih

\begin{tabular}{|c|l|c|c|}
\hline & $\begin{array}{c}\text { Nama } \\
\text { Dusun }\end{array}$ & Jumlah & $\begin{array}{c}\text { Prosentase } \\
\text { (\%) }\end{array}$ \\
\hline 1 & Karangjuwet & 63 & 26 \\
\hline 2 & Jaraan & 40 & 16 \\
\hline 3 & Karangan & 110 & 44 \\
\hline 4 & Borogragal & 35 & 14 \\
\hline & & 248 & 100 \\
\hline
\end{tabular}

Sumber: Data Primer Setelah Diolah

Dari Tabel 3 diketahui bahwa konsentrasi keberadaan UMKM terletak pada desa Karangan mencapai hampir 50\%. Hal ini disebabkan berbagai faktor antara lain letak di perbatasan antara 3 dusun dari 2 desa perbatasan yaitu Desa Girimoyo dan Desa Donowarih, serta juga luas wilayah yang lebih luas dibanding dengan dusun yang lain, dan merupakan titik pertemuan antara 5 (lima) dusun yang berasal dari 2 desa yaitu Dusun Suwaluhan, Dusun Kali Malang, Dusun Kali Malang dari desa Tawangargo, Dusun Borogragal dan Dusun Karangan dari Desa Donowarih. Dusun Karangjuwet juga merupakan dusun yang berkembang dengan pesat, mengingat lokasinya yang dekat dengan pasar Karangploso serta terdapat kawasan Rest Area Karangploso yang baru saja dibangun. Hal ini dapat dikatakan sebagai stimu- lus bagi suatu kawasan untuk lebih berkembang. Kawasan Karangjuwet termasuk kawasan yang tumbuh berbagai UMKM yang lebih bervariatif, karena adanya lokasi industri kecil yang berasal dari luar kawasan Kecamatan Karangploso misalnya Kota Malang dan Surabaya. Selanjutnya adalah Dusun Jaraan dan Dusun Borogragal di mana 2 dusun ini dengan keberadaan UMKM yang lebih sedikit dibandingkan 2 dusun lainnya. Dusun Jaraan terletak diantara 2 dusun yaitu Dusun Karangan dan Dusun Karangjuwet. Sedangkan untuk Dusun Borogragal adalah satu wilayah yang paling marginal di mana lokasinya terpisah dibandingkan dengan dusun lainnya di Desa Donowarih. Dusun Borogragal mempunyai jumlah dan keberagaman UMKM yang lebih sederhana dibandingkan dengan kawasan dusun yang lain. Jumlah UMKM menurut jenis usaha dapat dilihat pada Tabel 4 di bawah ini.

Tabel 4

Jumlah dan Jenis Usaha UMKM di Desa Donowarih

\begin{tabular}{|c|c|c|c|}
\hline No & Jenis Usaha & Jumlah & $\begin{array}{c}\text { Persentase } \\
(\%)\end{array}$ \\
\hline 1 & Bakso & 17 & 6,85 \\
\hline 2 & Penjual Sayur Mayur & 11 & 4,43 \\
\hline 3 & Bengkel & 5 & 2,02 \\
\hline 4 & Cilok & 12 & 4,84 \\
\hline 5 & Gorengan & 6 & 2,42 \\
\hline 6 & Pracangan & 127 & 51,21 \\
\hline 7 & Warung & 10 & 4,03 \\
\hline 8 & Mebel & 8 & 3,23 \\
\hline 9 & Konter & 10 & 4,03 \\
\hline 10 & $\begin{array}{l}\text { Pengolahan Bahan } \\
\text { Baku Pangan }\end{array}$ & 4 & 1,61 \\
\hline 11 & Mainan Anak & 3 & 1,21 \\
\hline 12 & Penjual Es & 6 & 2,42 \\
\hline 13 & Toko Obat & 5 & 2,02 \\
\hline 14 & Toko Bangunan & 2 & 0,81 \\
\hline 15 & Nasi Goreng & 2 & 0,81 \\
\hline 16 & Makanan Kecil & 3 & 1,21 \\
\hline \multirow[t]{2}{*}{17} & Lainnya & 17 & 6,85 \\
\hline & & 248 & 100 \\
\hline
\end{tabular}

Sumber: Data Primer Setelah Diolah 
Dari Tabel 4 terlihat pada UMKM di Desa Donowarih terdapat 2 bidang usaha yang paling banyak diminati yaitu: pracangan dan penjual bakso. Berdasarkan pada jenis usaha UMKM bisa dianalisis bahwa pemanfaatan dari lokasi yang dekat daerah dengan nilai atraktif yang tinggi misal Kota Batu sebagai Kota Wisata, dan masih banyaknya penggunaan teknologi yang masih sederhana. Jenis usaha pracangan merupakan jenis usaha UMKM yang paling banyak dipilih oleh pelaku usaha. Usaha ini pada umumnya tersebar merata di seluruh wilayah di Desa Donowarih bahkan lingkungan RT mempunyai lebih dari 2 toko pracangan. Jenis usaha lain yang banyak dipilih adalah pengolahan makanan antara lain: penjual bakso, cilok, nasi goreng dan sebagainya. Jenis usaha ini masih berdasarkan pada permintaan lokal setempat, belum adanya pengembangan ke tingkat yang lebih tinggi. Pada umumnya UMKM hanya menggunakan teknologi yang masih sederhana. Namun masih terdapat beberapa perusahaan menengah yang sudah menggunakan teknologi madya dalam operasionalnya, misal perusahaan makanan ringan (chiki). Jenis usaha lain yaitu UMKM yang bergerak di bidang penjualan buah/sayur. Bidang usaha ini didukung dari mayoritas pekerjaan di Desa Donowarih yang masih berdasarkan pada pertanian. Pekerjaan pertanian di Desa Donowarih didukung oleh kondisi geografis dan topografis yang ada, misal tanah yang subur, cuaca yang mendukung, pengetahuan pertanian yang baik dari petani, dan penerapan teknologi pertanian yang baik. Adanya kemudahan ini mendorong beberapa kelompok orang memillih jenis usaha di bidang pertanian, khususnya usaha perdagangan hasil pertanian. Di sisi lain jenis usaha yang bersifat manufaktur dengan teknologi madya sudah diaplikasikan pada operasionalnya. Beberapa bidang usaha antara lain mebel dan beberapa penghasil peralatan rumah tangga. Usaha ini muncul karena adanya hasil kehutanan yang berupa kayu pinus. Perkembangan usaha ini terus bertambah, dikarenakan banyaknya kawasan pemukiman baru yang terdapat di Desa Donowarih yang ikut mendorong perkembangan usaha ini. Untuk usaha jasa dan lainnya di wilayah ini terus mengalami perkembangan yang signifikan dengan semakin berkembangnya dan beragamnya kebutuhan masyarakat. Jenis usaha jasa UMKM yang terus berkembang adalah beberapa usaha yang lahir dari potensi daerah dalam hal ini lingkungan dan manusia misalnya konter pulsa, salon, pengecatan, pengelasan dan lain-lain. UMKM yang bergerak di bidang jasa ini ke depannya akan semakin banyak secara kuantitas dan kualitas. Namun untuk berkembang lebih jauh dibutuhkan sentuhan teknologi dalam proses operasionalnya.

Pada Tabel 5 ditunjukkan sebaran jumlah UMKM per-jenis usaha untuk masing-masing dusun/dukuh. Tabel 5 menunjukkan bahwa untuk wilayah Dusun Karangjuwet yang lokasinya dekat dengan daerah perdagangan dan pariwisata mempunyai karakteristik yang berbeda. Dalam hal ini UMKM yang bergerak dibidang pengolahan makanan dan minuman menjadi jenis usaha yang mayoritas dibanding dengan jenis usaha yang lain dengan prosentase sebesar 50,79\%. Lebih tinggi jika dibandingkan dengan dusun lainnya, di mana UMKM yang bergerak dibidang pengolahan makanan dan minuman untuk Dusun Jaraan 
sebesar 25\%, Dusun Karangan sebesar 19.09\% dan Dusun Borogragal sebesar 11.43\%. Bisa ditarik kesimpulan bahwa jenis usaha UMKM di bidang pe- ngolahan dan minuman lebih mempunyai elastisitas dengan lokasi perdagangan ataupun wisata (Rest Area Karangploso).

Tabel 5

Sebaran Jenis Usaha Berdasarkan Wilayah Dusun

\begin{tabular}{|c|c|c|c|c|}
\hline No. & Nama Dusun & Jenis Usaha & Jumlah & $\begin{array}{c}\text { Prosentase } \\
(\%)\end{array}$ \\
\hline 1 & Dusun Karangjuwet & $\begin{array}{l}\text { - Makanan/Minuman } \\
\text { - Pracangan } \\
\text { - Buah/Sayur } \\
\text { - Manufaktur } \\
\text { - Jasa/Lain-lain }\end{array}$ & $\begin{array}{c}32 \\
24 \\
2 \\
3 \\
2\end{array}$ & $\begin{array}{c}50,79 \\
38,09 \\
3,18 \\
4,76 \\
3,18\end{array}$ \\
\hline 2 & Dusun Jaraan & $\begin{array}{l}\text { - Makanan/Minuman } \\
\text { - Pracangan } \\
\text { - Buah/Sayur } \\
\text { - Manufaktur } \\
\text { - Jasa/Lain-lain } \\
\end{array}$ & $\begin{array}{c}10 \\
21 \\
3 \\
2 \\
4\end{array}$ & $\begin{array}{c}25 \\
52,5 \\
7,5 \\
5 \\
10 \\
\end{array}$ \\
\hline 3 & Dusun Karangan & $\begin{array}{l}\text { - Makanan/Minuman } \\
\text { - Pracangan } \\
\text { - Buah/Sayur } \\
\text { - Manufaktur } \\
\text { - Jasa/Lain-lain } \\
\end{array}$ & $\begin{array}{c}21 \\
58 \\
14 \\
6 \\
11\end{array}$ & $\begin{array}{c}19,09 \\
52,73 \\
12,73 \\
5,45 \\
10 \\
\end{array}$ \\
\hline 4 & Dusun Borogragal & $\begin{array}{l}\text { - Makanan/Minuman } \\
\text { - Pracangan } \\
\text { - Buah/Sayur } \\
\text { - Manufaktur } \\
\text { - Jasa/Lain-lain }\end{array}$ & $\begin{array}{c}4 \\
24 \\
4 \\
1 \\
2\end{array}$ & $\begin{array}{c}11,43 \\
68,57 \\
11,43 \\
2,86 \\
5,71\end{array}$ \\
\hline
\end{tabular}

Sumber: Data Primer Setelah Diolah

Untuk jenis UMKM bidang Pracangan masih menjadi mayoritas untuk 3 wilayah di Desa Donowarih kecuali Dusun Karangjuwet. Karakteristik dari bidang usaha ini adalah daerah pemasaranya yang hanya melayani lingkungan sekitar atau tingkat RT sehingga bisa disimpulkan bidang usaha ini berskala kecil baik dari segi pemasaran atau skala modal. Prosentase UMKM yang bergerak di bidang pracangan pada masing-masing dusun seperti terlihat pada Tabel 5 adalah Dusun Borogragal dengan prosentase sebesar 68,57\%, Dusun Karangan sebesar 52,73\% dan Dusun Jaraan sebesar 52,5\%. Jenis UMKM lainnya adalah penjualan buah dan sayur yang mana profesi ini memang dari petani yang mempunyai usaha perdagangan ataupun pelaku usaha perdagangan di bidang pertanian. Dari Tabel 5 diketahui bahwa prosentase UMKM yang bergerak di bidang penjualan buah dan sayur Dusun Karangan sebesar 12,73\% dan Dusun Borogragal sebesar 11,43\% menjadikan karakteristik tersendiri jika dibandingkan dengan daerah dusun yang lain. Jenis UMKM ini menjadi pilihan pelaku usaha dikarenakan seca- 
ra geografis dan topografis lebih mendukung terbentuknya jenis usaha pertanian. Banyaknya lahan dan lingkungan yang lebih jauh dari pusat perekonomian memberikan aksesibilitas pembentukan usaha di bidang pertanian.

\section{Kondisi Manajemen pada UMKM di Desa Donowarih UMKM Bidang Pengolahan Makanan dan Minuman \\ - Operasional}

Kegiatan operasional pada UMKM jasa pengolahan makanan dan minuman pada umumnya masih menggunakan teknologi tingkatan rendah, biarpun ada juga yang tingkat madya. Untuk penggunaan teknologi yang rendah produk yang dihasilkan masih banyak menggunakan tenaga manusia dan peralatan yang masih sederhana. Beberapa produk makanan dan minuman yang dihasilkan memang belum mempunyai standar kesehatan yang baik, kecuali ada beberapa produk yang dihasilkan dari teknologi yang lebih tinggi mereka sudah mengerti tentang pengolahan dan persyaratan produk yang sesuai dengan aturan yang berlaku.

\section{- Sumber Daya Manusia}

UMKM yang bergerak di bidang makanan dan minuman ini dalam penggunaan sumber daya manusia sebagian besar masih menggunakan jasa dari keluarga. Pemilik dan tenaga kerja menjadi satu bagian dalam usaha ini. Hal ini berlaku pada usaha-usaha yang bersifat rumah tangga yang lebih memfokuskan pada pemenuhan kebutuhan rumah tangga atau kebutuhan yang tidak berjangka panjang atau tidak adanya rencana-rencana pengembangan usaha yang lebih terinci. Beberapa usaha sudah menggunakan jasa/tenaga orang lain di mana kondisi usaha yang dijalankan telah mempunyai perencanaan bisnis yang lebih baik, yang pada awalnya usaha yang dijalankan bersifat rumah tangga. Dari segi pendidikan pada umumnya masih bersifat menengah ke bawah masih banyaknya tenaga manusia yang berpendidikan rendah misal SD ataupun SMP. Hal ini tidak salah dikarenakan teknologi yang digunakan tidak membutuhkan keterampilan yang tinggi atau bisa karena terbiasa.

\section{- Keuangan}

Pengelolaan keuangan yang dijalankan pelaku UMKM ini mayoritas masih menggunakan manajemen rumah tangga atau tidak adanya laporan keuangan yang sistematis. Banyak faktor menyebabkan hal ini terjadi misal: kurang mengertinya tentang pembuatan laporan keuangan, kurangnya mempunyai rencana terhadap usahanya, kurang mengerti manfaat dari laporan keuangan yang baik, atau faktor lainnya. Untuk perusahaan yang baik, mereka sudah melakukan laporan keuangan yang sistematis, dan melakukan beberapa kewajiban misal pajak ataupun THR bagi karyawannya.

\section{- Pemasaran}

Untuk sistem pemasaran yang digunakan lebih cenderung personal selling pada tempat yang lebih tetap. Cara ini lebih lebih sederhana dan kemampuan dalam mengambil informasi tentang pemasaran misalnya keinginan konsumen belum menyentuh. Pelaku bisnis ini masih berorientasi pada produk yang mereka hasilkan bukan pada kebutuhan 
konsumen yang terus berubah. Mayoritas produk yang dijual masih seragam dengan produk yang dihasilkan oleh usaha sejenis lainnya, dan tidak ada ciri khusus yang membedakan dengan usaha lain yang sejenis. Hal ini bisa mengakibatkan persaingan yang tidak baik, cenderung terjadi penurunan harga yang pada akhirnya mengurangi cashflow dan perkembangan usaha.

\section{UMKM Bidang Perdagangan Pracangan \\ - Operasional \\ Keadaan toko pracangan yang} dikelola oleh keluarga mempunyai karakteristik yang berbeda, dalam hal ini bisa dibagi berdasarkan lokasi. Keberadaan usaha toko pracangan yang berada di pinggir jalan utama di Desa Donowarih mempunyai kemampuan usaha yang lebih baik. Hal ini dibuktikan mereka mempunyai kemampuan dalam melihat persaingan usaha yang lebih baik, misalnya adanya toko mini market nasional yang berada tidak jauh dari tempat usahanya, dapat memberikan wawasan bagaimana cara melakukan usaha yang lebih baik. Untuk lokasi usaha yang berada di tengah dusun, mereka lebih berorientasi pada kebutuhan lingkungan sekitar. Pada jenis produk yang diperdagangkan lebih cenderung pada bahan pokok dan beberapa makanan kecil untuk anak- anak.

\section{- Sumber Daya Manusia}

Penggunaan tenaga kerja manusia pada jenis usaha UMKM ini lebih didasarkan pada pemilik menyatu dengan pekerja ataupun adanya hubungan keluarga. Hal ini terjadi karena kebutuhan manajemen pengelolaan usaha ini masih bersifat sederhana.

\section{- Keuangan}

Dari segi keuangan, manajemen yang digunakan masih menyatu dengan keuangan pribadi. Margin yang didapat masih digunakan untuk kepentingan konsumtif, sehingga penggunaan cashflow yang masih berdasarkan pada stok barang yang ada dan intuisi.

\section{- Pemasaran}

Untuk pemasaran yang digunakan masih sangat sederhana. Keberadaan usaha yang didasarkan pada penduduk sekitar, produk yang dijual masih homogen, sehingga strategi yang digunakan hanya berdasarkan pada kemampuan modal dan harga. Hal ini bisa mengakibatkan rendahnya kemampuan usaha dalam jangka panjang, karena cash flow yang rendah dan tidak menguntungkan bagi pemilik usaha.

\section{UMKM Bidang Perdagangan Buah dan Sayur \\ - Operasional}

Untuk pengelolaan secara operasional dalam jenis usaha UMKM ini memiliki tingkat yang lebih baik, biarpun hanya beberapa pedagang sayur/buah yang masih menggunakan sistem yang masih sederhana. Sebagian dari pelaku usaha sudah melakukan kerjasama dengan para petani dan pihak ketiga untuk memasok bahan baku atau produk. Hal ini menggambarkan bahwa adanya perkembangan manajemen pengelolaan usaha untuk menjamin kontinuitas produk. Hal ini merupakan salah satu cara memberikan kepercayaan atau good will kepada stakeholder. Satu hal lainnya adalah 
penggunaan media sosial atau perangkat komunikasi lainnya yang dapat menunjang peningkatan kapasitas usaha. Satu faktor lainnya adalah adanya pasar yang dekat yaitu Pasar Karangploso yang mana saat ini menjadi barometer sayurmayur di Kabuaten Malang dan Kota Batu, sehingga pelaku usaha perdagangan sayur dan buah yang berada di wilayah Donowarih mempunyai informasi dan jaringan kerja yang baik.

\section{- Sumber Daya Manusia}

Pemanfaatan sumber daya manusia pada jenis usaha ini sudah lebih baik, adanya tenaga kerja yang diambil berdasarkan pengalaman dan bukan dari sisi kekeluargaan. Beberapa keterampilan yang dibutuhkan yaitu pencucian, penanganan pasca panen dan pengemasan produk. Hasil produk pertanian yang dominan di Desa Donowarih adalah sayuran-sayuran misal sawi, tomat, cabai, sawi putih, dan buah-buahan misal: jeruk baik keprok ataupun siem dan apel. Salah satu sentra jeruk keprok batu 55 adalah Desa Donowarih, maka tidak heran Desa Donowarih ini mempunyai nama sampai tingkat Jawa Timur. Kondisi yang kondusif ini mempunyai efek positif terhadap pelaku usaha perdagangan dan juga petaninya, baik untuk jaringan kerja, informasi, pengetahuan di bidang-bidang yang lainnya misal: pengemasan, kualitas produk, penanganan pasca panen dan sebagainya.

\section{- Keuangan}

Pelaku UMKM bidang perdagangan sayur dan buah pada intinya sudah melakukan sistem laporan keuangan yang sederhana terbukti dengan adanya catatan kecil tentang cashflow, biarpun belum termasuk laporan yang sistematis. Beberapa hal yang menyebabkan mereka telah menggunakan atau membuat laporan keuangan adalah tingginya kegiatan operasional usahanya. Banyak stakeholder yang terlibat menuntut mereka untuk lebih berhatihati dalam mengelola usahanya misalnya pemesanan produk ke petani, tenaga kerja, transportasi yang digunakan, pembeli dari daerah lain.

\section{- Pemasaran}

Daerah pemasaran untuk jenis UMKM perdagangan sayur dan buah masih berpusat pada daerah Kecamatan Karangploso, dengan lokasi pasar sebagian besar diperdagangkan di Pasar Karangploso, Kabupaten Malang. Selanjutnya oleh pembeli grosir disebar ke daerah lainnya termasuk Kota Surabaya, Kota Batu dan Daerah Kabupaten Malang lainnya. Jaringan pemasaran yang dibentuk didasar atas sering bertemunya antara penjual di dalam satu lokasi dan secara langsung melakukan kerjasama diantaranya. Pasar Karangploso yang terletak di Kecamatan Karangploso merupakan pasar sayur terbesar di Malang Raya, sehingga pedagang sayur dan buah di Desa Donowarih mempunyai keuntungan yaitu mudahnya mencari akses pasar yang lebih luas. Terbukti banyaknya stakeholder yang datang di Pasar Karangploso untuk melakukan transaksi penjualan, bahkan pedagang ataupun petani melakukan penjualan secara langsung di Pasar Karangploso.

\section{UMKM Bidang Manufaktur}

- Operasional

Jenis UMKM yang bergerak di bidang manufaktur mempunyai gam- 
baran telah menggunakan teknologi tingkat madya. Hal ini berbeda sekali jika dibandingkan kurun waktu 10 tahun yang lalu, semua pekerjaan masih bersifat konvensional, karena kendala peralatan/mesin yang masih sederhana. Beberapa jenis usaha manufaktur antara lain: pembuatan mebel kayu mendapatkan kemudahan dalam hal pembelian bahan baku, karena Desa Donowarih sebagai salah satu produsen kayu olahan, untuk jenis kayu yang lain yang tidak tersedia biasanya pelaku usaha mencari di daerah lain yang mana sudah terjalin kerja sama. Sistem operasional masih didasarkan pada pemesanan yang datang dan bersifat lokal atau di lingkungan sekitar.

\section{- Sumber Daya Manusia}

Dalam usaha ini penggunaan sumber daya manusia relatif telah mempunyai keahlian yang baik, biarpun masih ada unsur kekeluargaan tetapi pemilihan karyawan telah menggunakan sistem on the right man on the right place, yang mana karyawan ditetapkan pada pekerjaan yang sesuai dengan keterampilan.

\section{- Keuangan}

Pengelolaan keuangan pada usaha ini sebagian besar masih menggunakan sistem keuangan tradisional/ kekeluargaan, belum adanya laporan yang bersifat sistematis, sehingga masih perlunya pelatihan keuangan yang baik, mengingat perkembangan usaha yang semakin baik tiap tahunnya sejalan perkembangan di daerah Desa Donowarih.

\section{- Pemasaran}

UMKM mebel yang terdapat di Desa Donowarih memasarkan produk yang dihasilkan tidak saja dijual untuk konsumen lokal, melainkan dipasarkan di luar daerah Kecamatan Karangploso. Sistem pemasaran yang telah dilakukan masih bersifat sederhana yaitu masih menggunakan Personal Selling. Jadi perlu diadakan peningkatan dan pengembangan penggunaan media pemasaran yang jangkauannya lebih luas misal: internet atau media sosial yang lain.

\section{KESIMPULAN}

Kebanyakan kegiatan operasional yang dilakukan oleh unit usaha UMKM masih sederhana dan parsial. Seringnya kekurangan yang dihadapi dalam pengelolaan UMKM adalah kegiatan operasional dilakukan atau diputuskan berdasarkan pertimbangan pada satu sisi saja, misal sisi keuangan saja, teknis saja atau pemasaran saja, belum adanya rancangan strategi yang simultan, bersifat perbaikan menyeluruh, integratif dan berkesinambungan. Di sini peran pemerintah seharusnya bisa memberikan program-program peningkatan keterampilan manajemen, baik itu soft skill ataupun hard skill.

Pada umummnya UMKM yang berada di Desa Donowarih hanya sebagian kecil saja yang menyusun laporan keuangan yang sistematis, sehingga pelaku UMKM tersebut mampu untuk mengembangkan usahanya lebih luas. Efek yang diterima adalah tidak adanya akses pada lembaga keuangan yang baik guna meningkatkan operasional usaha semisal penggunaan teknologi informasi.

\section{SARAN}

1. Belum adanya pemahaman yang baik tentang bantuan modal pemerintah yang telah diberikan kepada pelaku UMKM, pada dasarnya persepsi dari pemberian modal 
itu bersifat sosial atau charity, sehingga dana tersebut yang harusnya wajib dikembalikan kembali, tapi tidak dilakukan atau tidak dipertanggungjawabkan. Di sini perlu adanya pemahaman-pemahaman tentang etika bisnis yang bisa dikembangkan dengan cara pelatihan-pelatihan soft skill.

2. Dalam pengelolaan keuangan, modal yang dimiliki umumnya beromset kecil dan berdasarkan pada hitungan harian dan pengaturan antara kepentingan pribadi, perusahaan dan pos lainnya tercampur. Belum adanya catatan yang sistematis dan administratif (arus kas, neraca, laporan laba rugi), ketidakjelasan antara laba dan rugi, yang membuat mereka tidak mengetahui gambaran usaha mereka, apakah keuntungan atau kerugian yang mereka dapatkan.

3. Belum optimalnya konektivitas antara usaha yang satu dengan usaha yang lain. Misalnya adanya usaha, yang cenderung dijalankan masih sendiri-sendiri, adanya persaingan yang kurang baik diantara pelaku usaha. Akibat dari hal ini adalah kurang baiknya dalam penentuan margin harga yang tidak sehat bagi keberlangsungan usaha.

4. Segmen pasar yang dituju paling besar didasarkan pada segmen golongan menengah ke bawah, sehingga keuntungan yang diraih juga cenderung sangat kecil yang selanjutnya akan membawa kesulitan dalam pengembangan usaha yang lebih luas.

5. Kurangnya keahlian dan keterampilan khusus, sehingga produk yang dihasilkan belum dapat memenuhi kebutuhan ataupun kriteria pada golongan konsumen tertentu serta jumlah permintaan di pasar.

6. Masih menggunakan sistem kekeluargaan dalam pengambilan karyawan, tanpa melalui prosedur yang baik dan kebanyakan pekerja yang berasal dari keluarga mempunyai kecenderungan susah untuk mengerti tentang aturan-aturan yang sudah ditetapkan oleh pemilik usaha.

7. Kurang baiknya akses ke lembaga keuangan yang dapat meningkatkan modal ataupun usaha. Hal ini disebabkan kurangnya pemberian deskripsi usahanya kepada pihak kedua untuk syarat dalam peminjaman modal.

8. Tidak mampunya membuat perencanaan bisnis tentang usaha ke depannya, sehingga operasional atau kegiatan yang dilakukan masih bersifat rutinitas tanpa adanya target-target ataupun program yang digunakan untuk peningkatan usaha.

9. Dari segi mental adalah kurang adanya keberanian dalam mengambil resiko. Semisal adanya usaha yang berjalan dari keluarga 2 generasi dengan alasan menjaga amanah tanpa adanya perubahan mempunyai dampak kurang baik baik pelaku usaha

\section{DAFTAR KEPUSTAKAAN}

Assery, S., 2009, Strategi Mempercepat Pemberdayaan UMKM, Harian Suara Merdeka, 27 Mei 2009.

Chambers, Robert, 1995, Poverty and Livelihoods: Whose Reality Counts? In People: From Impoverishment to Empowerment, ed. Uner Kirdar dan Leonard Silk, 1- 
16, New York University Press, New York.

Cholisin, 2011, Pemberdayaan Masyarakat, Disampaikan Pada Gladi Manajemen Pemerintahan Desa Bagi Kepala Bagian/Kepala Urusan Hasil Pengisian Tahun 2011 Di Lingkungan Kabupaten Sleman, www.pemberdayaanmasyarakat. com, Diakses tanggal 7 Maret 2014.

Heri, 2012, Peranan UKM terhadap Pertumbuhan di Indonesia, http:// h3r1y4d1.wordpress.com/2012/03/1 2/peranan-ukm-terhadap-pertumbuhan-ekonomi-di-indonesia, Diakses 7 Maret 2014.

Payu, Boby Rantow dan Sri Indriyani S. Dai, 2014, Pemetaan UKM di Kota Gorontalo Berdasarkan Pola dan Tingkat Penggunaan Teknologi Informasi, Laporan Penelitian, Program Studi Pendidikan Ekonomi, Jurusan Pendidikan Ekonomi, Fakultas Ekonomi dan Bisnis, Universitas Negeri Gorontalo.
Peraturan Menteri Dalam Negeri Nomor 7 Tahun 2007 tentang Kader Pemberdayaan Masyarakat.

Soekartawi, 2005, Agribisnis Teori dan Aplikasinya, PT. Raja Gafindo Persada, Jakarta.

Soetomo, 2011, Pemberdayaan Masyarakat Mungkinkah Muncul Antitesisnya, Pustaka Pelajar, Yogyakarta.

Sudarajat, 2012, Pemberdayaan UMKM Dalam Mewujudkan Tujuan Pembangunan Milenium (Penanggulangan Kemiskinan), UPBJJ -UT, Denpasar.

Sumodiningrat, Gunawan, 2002, Memberdayakan Masyarakat, Perencana Kencana Nusadwina, Jakarta.

Undang-Undang Republik Indonesia Nomor 20 Tahun 2008 tentang Usaha Mikro, Kecil, dan Menengah (UMKM). 